\title{
The Utility of Vascular Dysfunction Studies in the Prediction and Preven- tion of Preeclampsia: A Historical Review
}

\author{
Keiichi Matsubara*, Yuko Matsubara and Masaharu Ito
}

Department of Obstetrics and Gynecology, Ehime University School of Medicine, Shitsukawa, Toon, Ehime 791-0295, Japan

\begin{abstract}
Preeclampsia is a major cause of maternal and perinatal mortality. Although preeclampsia may be caused by several factors, endothelial cell dysfunction has been proposed as the main pathophysiological cause. Dysfunctional endothelium in the uteroplacental circulation not only increases peripheral vascular resistance, but also affects generalized vasoconstriction via humoral factors released from the placenta. A standard method for predicting and preventing preeclampsia has yet to be developed; however, the analysis of a combination of biochemical markers, particularly markers related to vascular dysfunction, may enhance our ability to predict and prevent preeclampsia in the near future.
\end{abstract}

Keywords: Angiogenic growth factor, endothelial cell activation, inflammatory response, oxidative stress, preeclampsia.

\section{INTRODUCTION}

Preeclampsia, known as gestational hypertension with proteinuria, complicates $5 \%$ to $8 \%$ of all pregnancies. Despite the current state of perinatal care, preeclampsia continues to be associated with high perinatal mortality and intrauterine fetal growth retardation [1]. In cases of severe preeclampsia after the 28th gestational week, early delivery is typically preferred in order to improve the neonatal prognosis. Ninety percent of preeclampsia occurs after 34 weeks' gestation, the time at which prognosis is relatively good. Early-onset preeclampsia (before 32 weeks gestation), however, can be serious; and delivery can be associated with elevated neonatal morbidity and mortality rates in preeclamptic women $[2,3]$. At-risk pregnant women who develop preeclampsia should be subjected to close maternal and fetal surveillance, especially in the second and early third trimesters [2]. Low-calorie and appropriate sodiumrestricted diets may retard the development of preeclampsia and thereby improve perinatal outcome [3].

The development of methods to predict and prevent preeclampsia in early pregnancy is important for management of this condition. Although many investigators have sought to develop practical screening tests for the prediction of preeclampsia, these tests have not attained sufficient sensitivity and specificity [4]. Recent research on vascular dysfunction, however, has provided results that may lead to the successful and reliable prediction of preeclampsia.

In this study, we reviewed the history of approaches employed to predict preeclampsia and prevent its onset. The first section includes a discussion of traditional prediction methods, of which uterine arterial doppler measurement dur-

*Address correspondence to this author at the Department of Obstetrics and Gynecology, Ehime University School of Medicine, Shitsukawa, Toon, Ehime 791-0295, Japan; Tel: +81-89-960-5379; Fax: +81-89-960-5381;

E-mail:keiichi@m.ehime-u.ac.jp ing the midtrimester has been the most effective. The second section presents the use of biochemical markers as a modern approach to preeclampsia prediction. Vascular dysfunction is a major cause of preeclampsia, and biochemical markers related to vascular function have been reported to predict preeclampsia onset. The third section reviews recent trials of treatments intended to prevent the onset of preeclampsia, including the use of vitamin $\mathrm{C}$ and $\mathrm{E}$. This field of study shows promising progress for preeclampsia prevention in the near future.

\section{RISK FACTORS FOR PREECLAMPSIA}

Women experiencing high-risk pregnancies should be identified in order to predict and prevent preeclampsia occurrence $[1,4-7]$. Although mild preeclampsia shows no familial tendency, family history of severe preeclampsia is a risk factor. In a study cohort of preeclamptic women, the mother of the preeclamptic women had a $14 \%$ rate of a history of severe preeclampsia, while unrelated controls (their mothersin-law) had a rate of only $3 \%$ [8]. Nulliparity is another risk factor, as preeclampsia has been diagnosed among $64 \%$ of nulliparous women and only $36 \%$ of parous women [9]. Women with a body mass index greater than 35 before pregnancy have a four-fold greater rate of preeclampsia than those with a body mass index in the range of 19-27 [10]. Furthermore, a low body mass index $(<20)$ reduces the prevalence of preeclampsia [11]. Multiple gestation is known to be a strong risk factor for preeclampsia. Coonrod et al. [12] reported that twin pregnancy carried a nearly four-fold increased risk for preeclampsia. Furthermore, pregnant women aged 40 years and older were more likely to develop preeclampsia (nulliparous: OR 1.8, 95\% CI 1.3-2.6; multiparous: OR 1.9, 95\% CI 1.2-2.9) leading to increased maternal morbidity [13].

Complications also contribute to the risk for preeclampsia. The incidence of preeclampsia was reportedly increased 
to $9.9 \%$ in diabetic pregnancies compared with $4.3 \%$ in nondiabetic controls [14]. Untreated hyperthyroidism is also known to stimulate preeclampsia-eclampsia; however, diagnosis of hyperthyroidism can reduce the incidence of preeclampsia through prompt management [15]. The prevalence of preeclampsia $(11.7 \%)$ in anti-cardiolipin antibodypositive women is significantly higher than that in other pregnant women (OR 1.9, 95\% CI 2.43-16.0) [16]. On the other hand, it has been reported that long-term semen exposure [17] and $\mathrm{T}$ cell immune deficiency [18] reduce the risk of preeclampsia.

\section{CLASSICAL PREDICTIVE APPROACHES}

Many methods intended to predict the onset of preeclampsia have been investigated throughout the history of research on this disease. These approaches have been based on the theory that vascular reactivity is elevated in pregnant women who develop preeclampsia. Although vascular responsiveness to angiotensin II (AngII) decreases early in normal pregnancy, pregnant women who subsequently develop preeclampsia are extremely sensitive to the pressor effects of infused AngII [19].

\section{Blood Pressure}

In normal pregnancy, blood pressure is lowest between 16 and 20 weeks' gestation and then gradually increases toward non-pregnant levels in the late stages of pregnancy. The mean level of diastolic blood pressure is usually less than $75 \mathrm{mmHg}$ in the middle of a normal pregnancy. Since vascular reactivity (especially to AngII) is stimulated in preeclampsia, the elevation of diastolic blood pressure may be a good predictor of preeclampsia. Caritis et al. [5] reported that the risk of preeclampsia was $8 \%$ for women with a mean arterial pressure of $<75 \mathrm{mmHg} v$ s. $27 \%$ for women with a mean arterial pressure $>85 \mathrm{mmHg}$. However, the predictive power for preeclampsia is very low $(20 \%)$ when the cutoff level for diastolic blood pressure is set at 80-85 $\mathrm{mmHg}[20]$. Simple blood pressure tests are thus not effective in predicting the occurrence of preeclampsia.

\section{Roll Over Test (ROT)}

The ROT evaluates the risk of preeclampsia by measuring elevation of blood pressure stimulated by a change of maternal position [21]. In the ROT, diastolic blood pressure levels during bed rest and after the change of maternal position are measured, and the difference between the two values is calculated. A positive ROT is defined as an elevation in diastolic blood pressure greater than $20 \mathrm{mmHg}$. The negative predictive value of this test is relatively high and its reproducibility is poor $[22,23]$.

\section{Handgrip Test (HGT)}

The HGT, performed before the 15th gestational week, measures the change in blood pressure induced by 3-5 min of sustained isometric exercise. Test results are considered positive if systolic blood pressure increases by $15 \mathrm{mmHg}$ or more during the isometric exercise or decreases by $14 \mathrm{mmHg}$ or more immediately after exercising. The negative predictive value of this test is high (98\%) [24].

\section{Angiotensin Sensitivity Test (AST)}

Although vascular sensitivity to AngII is reduced in normal pregnancy, pregnant women who develop preeclampsia show increased sensitivity to AngII [25]. The AST measures the dose of AngII required to raise systolic blood pressure by $20 \mathrm{mmHg}$ (effective pressor dose) at 26-32 weeks gestation. It has been reported that an effective pressor dose less than $12 \mathrm{ng} / \mathrm{kg} / \mathrm{min}$ can yield a high percentage of false-positive results [25]. This method is complicated and invasive, and the positive and negative predictive values are poor. Therefore, AST is not considered to be an effective screening test for preeclampsia [26].

\section{Doppler Ultrasonography (uterine arterial blood flow)}

In preeclampsia, trophoblast invasion into the uterine myometrium is poor and the reconstruction of spiral arteries fails. As a result, utero-placental perfusion is reduced. Reduced utero-placental blood flow can be measured with ultrasonography since uterine arterial flow reflects the change of spiral arterial flow [27]. Reduction in blood flow may be estimated from an elevation in the uterine arterial pulsatility index (PI) [28] or resistance index (RI) [29]. Also, the uterine arterial notch may be associated with the ischemic pathology of a preeclamptic placenta [30]. However, uterine arterial doppler measurement in mid trimester has been found to be deficient as a screening test for preeclampsia [31]. The reliability of these indices (PI, RI) is low since they are affected by multiple factors including placental position, uterine contractions, and maternal heartbeat. However, the examination has merits as an easy and non-invasive method. The sensitivity is $75 \%$, but the negative predictive value is high $(88 \%)$ [32].

\section{MODERN PREDICTIVE APPROACHES}

\section{Endothelial Cell Activation or Dysfunction}

While the pathophysiology of preeclampsia remains unclear, activation or dysfunction of the vascular endothelium in uteroplacental circulation has been proposed as a possible cause of preeclampsia [33]. Dysfunctional endothelium in the uteroplacental circulation not only increases peripheral vascular resistance, but also influences generalized vasoconstriction via humoral factors released from the placenta. Therefore, hypertension rapidly improves after delivery [33]. Since endothelial cells maintain the homeostasis of the coagulation cascade [34], the inflammatory process [35], and vascular tone [36], endothelial cell activation or dysfunction can affect thrombosis [34], inflammation [35], and hypertension [36].

In preeclampsia, increased vascular permeability decreases circulating plasma volume, which results in hemoconcentration. The vascular endothelial dysfunction that accompanies hemoconcentration can then lead to hypertensive disorder [37]. Placental ischemia, which is a characteristic of preeclampsia, is associated with a release of molecules from endothelial cells. Fibronectin, a high-molecular weight extracellular matrix glycoprotein produced by the endothelium, is involved in cellular interactions such as cell adhesion and migration. Plasma fibronectin concentration, which is thought to be an indicator of endothelial injury, is signifi- 
cantly increased in women with preeclampsia [38, 39], even before its clinical onset [40]. As mentioned above, endothelial cellular abnormality in the uteroplacental and fetoplacental circulation has recently attracted widespread attention as a possible cause of preeclampsia [33].

\section{Coagulation Cascade}

Platelet aggregation and coagulation cascade are stimulated in preeclampsia. Emonts et al. [41] attempted to develop a prediction index using APTT, PT, activated factor VIII, and free protein $\mathrm{S}$ in combination with relative plasma volume and maternal history of chronic hypertension. They demonstrated a satisfactory positive predictive value and cost efficiency ratio. Chappell et al. [42] demonstrated that an algorithm analysis involving the plasminogen activator inhibitor-1/plasminogen activator inhibitor-2 ratio and placenta growth factor (PlGF) could effectively predict preeclampsia.

\section{Inflammatory Response}

Endothelial activation or dysfunction initiated by lipid peroxidation and leukocyte activation may be a key process in the pathogenesis of preeclampsia. This possibility has been suggested because many indicators of a systemic inflammatory response are markedly changed in preeclampsia [43] and large numbers of inflammatory cells permeate outside the placental blood vessels during preeclampsia [44]. Raijmakers et al. reported that infusion of $\mathrm{TNF} \alpha$ and a proinflammatory cytokine caused hypertension in pregnant rats [45]. Indeed, serum concentration of $\mathrm{TNF} \alpha$ has been reported to be increased even before the onset of preeclampsia [46]. Furthermore, pregnant women who develop preeclampsia also have a high serum concentration of the soluble adhesion molecules sE-selectin and SICAM-1 in the first trimester [46]. TNF $\alpha$ promotes ICAM-1 and E-selectin activation on endothelial cells [47] and facilitates the membrane-bound ICAM-1 and E-selectin into the blood by shedding [48]. We suggest that the excessive amount of TNF $\alpha$ produced in the placenta early in pregnancy activates endothelial cells and promotes the expression of adhesion molecules. Endothelial activation or dysfunction caused by inflammatory reaction could reduce the production of prostacyclin [49] and nitric oxide [50], leading to impaired vascular relaxation. Markers of pro-inflammation and inflammation such as serum TNF $\alpha$, sE-selectin, and sICAM-1 might be predictive of preeclampsia.

\section{Angiogenic Growth Factor}

The pathophysiology of preeclampsia begins with placental dysfunction in the first trimester [51]. In normal pregnancy, extravillus trophoblasts travel to the maternal spiral arteries during the first trimester [52]. Vascular endothelial growth factor (VEGF) and PlGF, which are strong proangiogenic proteins, are expressed in the trophoblasts and play a role in the process of spiral artery remodeling in normal pregnancy $[53,54]$. Adequate placentation relies on appropriate fetoplacental vascular networking including spiral artery remodeling. VEGF stimulates endothelial cell growth and migration, and promotes angiogenesis during embryonic development. PIGF shares 53\% homology with VEGF at the amino acid level and its angiogenic function is similar to
VEGF. Trophoblasts strongly express PlGF and the receptor is predominantly expressed. Serum PlGF levels rise during the first and second trimesters of pregnancy, peaking early in the third trimester [55]. They are involved in an early stage of the process of placentation. In preeclampsia, free PlGF concentration in serum was found to be reduced compared with normal pregnancy $[55,56]$, and the serum level was already reduced before 20 weeks' gestation in women who would later develop preeclampsia [55]. Decreased levels of free PlGF could influence endothelial cell and trophoblast function, thereby contributing to the pathogenesis of preeclampsia.

Soluble fms-like tyrosine kinase 1 (sFlt-1), a circulating anti-angiogenic protein, is increased in the placenta and serum of women with preeclampsia [57]. sFlt-1 binds with VEGF and PlGF, preventing their interaction with endothelial Flt-1 and KDR and thereby inducing endothelial dysfunction. Increased circulating sFlt-1 concentration beginning five weeks before the onset of preeclampsia is accompanied by decreases in free PlGF and VEGF levels in maternal circulation. Measurement of the serial concentrations of sFlt-1 and free PlGF throughout pregnancy may allow researchers to better assess the relevance of these markers in the early identification of preeclampsia [58].

\section{Cell-Free Fetal DNA in Maternal Circulation}

Cell-free fetal DNA in maternal circulation allows noninvasive prenatal diagnosis [59] since cell-free DNA can be derived from fetal white blood cells or fetal nucleated red blood cells. Fetal DNA in maternal circulation, however, is primarily derived from the placenta [60] since cell-free DNA is not correlated with fetal white or nucleated red blood cell counts, or the amount of fetal DNA [61].

Recent analysis of placental DNA and RNA in maternal plasma indicates that the nucleotide molecules could represent a preeclampsia predicting marker. There is a significant increase in the shedding of cellular debris, including syncytiotrophoblast microparticles, in preeclampsia that is not seen in normal pregnancy. It is thought that the debris results from normal renewal and repair, and that it is increased in preeclampsia due to syncytial apoptosis caused by placental hypoxia [62]. Syncytiotrophoblast microparticles, including cell-free DNA and mRNA, are released from the surface of the placenta into the maternal circulation. Mechanical damage to placental syncytiotrophoblasts may particularly increase syncytiotrophoblast microparticles in maternal circulation during preeclampsia [63]. A recent study reports that placenta-derived hypermethylated $R A S S F 1 A$ gene, a tumor suppressor gene, in maternal circulation can be utilized as a universal fetal marker regardless of fetal sex or genetic variations [64]. Furthermore, Tsui et al. insist that quantitative aberrations of hypermethylated $R A S S F 1 A$ in the maternal plasma of preeclamptic women represent a potentially useful non-invasive measure for the prenatal assessment of preeclampsia [65].

\section{Neurokinin B}

The biological actions of neurokinin B, a tachykinin peptide in the family of peptides that comprise substance $\mathrm{P}$, include smooth muscle contraction, pain transmission, neuro- 
genic inflammation, and activation of the immune system [66A]. However, neurokinin B is undetectable in the peripheral tissues of non-pregnant animals [67A]. Neurokinin B is expressed at the outer syncytiotrophoblast of the placenta, and its secretion into both fetal and maternal circulation originates mainly from the placenta. Normally, neurokinin B can be detected in plasma as early as the ninth week of gestation, increases in mid and late pregnancy, and then decreases rapidly after delivery [68]. Plasma concentration of neurokinin $\mathrm{B}$ is markedly elevated in preeclampsia $[67,69,70]$. Expression of the neurokinin $\mathrm{B}$ receptor TAC3 is also significantly higher in preeclamptic placenta [71]. During pregnancy, activation of TAC3 by neurokinin $\mathrm{B}$ reduces the blood flow through the liver to satisfy the needs of the uterus and placenta.

\section{Oxidative Stress}

Hyperuricemia is a common finding in preeclampsia. It is usually considered secondary to altered renal function, increased tissue breakdown, and increased oxidative stress [72]. Uric acid is converted from the major purine nucleosides adenosine and guanosine through the purine catabolic pathway. The beneficial effects of uric acid include its antioxidant activity [73] and reduced nitrosylation of tyrosine residues on proteins by peroxynitrite [74]. Conversely, uric acid has pro-oxidant activity when other antioxidants are at low levels [75], and stimulates the inflammatory process that leads to endothelial dysfunction [76]. Uric acid-induced endothelial dysfunction could promote hypertension, vascular disease, and renal disease [76].

In normal pregnancy, uric acid has an antioxidant function [77]. The urate free radical created by the oxidation of uric acid [78], however, has the potential to go on to oxidatively modify placental proteins and lipids [79], leading to disturbed placentation and placental function. In women who develop preeclampsia, the plasma concentration of uric acid is increased at around 10 weeks of gestation- a development that precedes the clinical presentation of preeclampsia [80]. An increased serum uric acid level indicates underlying oxidative stress as these increased levels correlate with plasma hydrogen peroxide and plasma protein carbonyl levels in preeclampsia [81]. Increased placental oxidative stress in preeclampsia results from increased pro-oxidant generation coupled with insufficient antioxidant capacity. Furthermore, the plasma level of malondialdehyde, a major metabolite of lipid peroxide is increased in patients with preeclampsia [82]. Release of lipid peroxides into the maternal circulation and cytokine synthesis from activated neutrophils could contribute to maternal endothelial cell activation in preeclampsia [83].

Nicotinamide adenine dinucleotide phosphate-oxydase (NAD $(\mathrm{P}) \mathrm{H}$ oxidase) in the placenta could be an important source of superoxide during pregnancy and preeclampsia [45]. On the other hand, antioxidant capacity is known to be decreased in preeclampsia [84]. Decreased plasma levels of the major intracellular antioxidant glutathione [85] and vitamin $C$ [86] have been reported in women with preeclampsia. Hence, converting evidence suggests the pathophysiology of preeclampsia is characterized by increased oxidative stress and chronic inflammation.

\section{Neural Role in Vascular Dysfunction}

Quinn and colleagues suggested that a loss of vascular regulation in the uteroplacental circulation could result in uterine vasoconstriction, renal vasoconstriction, and maternal hypertension. This explanation is possible given that partial denervation at the endometrial-myometrial interface would prevent appropriate trophoblast invasion with a failure of adaptation of the uterine spiral arteries and generate a maternal cytokine response [87]. Given that regional uterine denervation related to curettage and back injury has been associated with cytokine responses including VEGF [88], investigation of some kinds of cytokines including sFlt-1 and neural originated cytokines, may be useful in elucidating a method for predicting onset of preeclampsia.

\section{PREVENTION OF PREECLAMPSIA}

Low-sodium diets, calcium supplementation [89], and bed rest have been used in traditional preventive management for preeclampsia. A large trial suggested that low-dose aspirin could reduce the occurrence of preeclampsia among high-risk women [90-92]. Conversely however, Caritis et al. [93] reported that low-dose aspirin treatment did not reduce the incidence of preeclampsia or improve perinatal outcomes in high-risk pregnant women.

Reduced intake of calcium is known to be associated with an elevated risk of preeclampsia [94]. Meanwhile pregnant women with high calcium intake levels had a very low incidence of eclampsia despite the presence of high-risk factors [95]. Biological demand for calcium is very high during pregnancy and calcium is necessary for fetal growth. Thus, it is not surprising that calcium supplementation was reported to help prevent preeclampsia among high-risk patients [94]. Other investigators, however, have not found significant effects related to high calcium intake $[1,96]$. It is possible that calcium supplementation may help preventing preeclampsia in populations whose typical diet is low in calcium [96A].

Diets rich in fruits and vegetables are associated with decreased mortality from cardiovascular disease [97]. A 37\% reduction of fruit intake is also associated with preeclampsia risk [98]. Furthermore, a diet rich in vegetables may alleviate the signs and symptoms of preeclampsia [99]. This association suggests that vitamins $\mathrm{C}$ and $\mathrm{E}$ afford protection against cardiovascular disease and preeclampsia by reducing oxidative tissue damage [100]. Vitamin E can interfere with $\mathrm{NAD}(\mathrm{P}) \mathrm{H}$ oxidase activity through the inhibition of protein kinase $\mathrm{C}$, leading to reduction of free radical generation [101]. Daily vitamin E supplementation in the dose range of 100-400 IU over 2 years or more was reported to be most efficacious in reducing low-density lipoprotein oxidation and positively influencing mortality rates from cardiovascular disease [100]. This antioxidant activity may also be beneficial for the prevention of preeclampsia due to its antiinflammatory effect. Persons with diabetes or hypertension have also been reported to benefit from supplemental vitamin C intake [100]. Chappell et al. reported that a combination of vitamins $\mathrm{C}$ and $\mathrm{E}$ could reduce the incidence of preeclampsia among high-risk women [102]. However, randomized trials failed to show any consistent benefit if vitamins $\mathrm{C}$ and $\mathrm{E}$ on cardiovascular disease [103, 104]. 


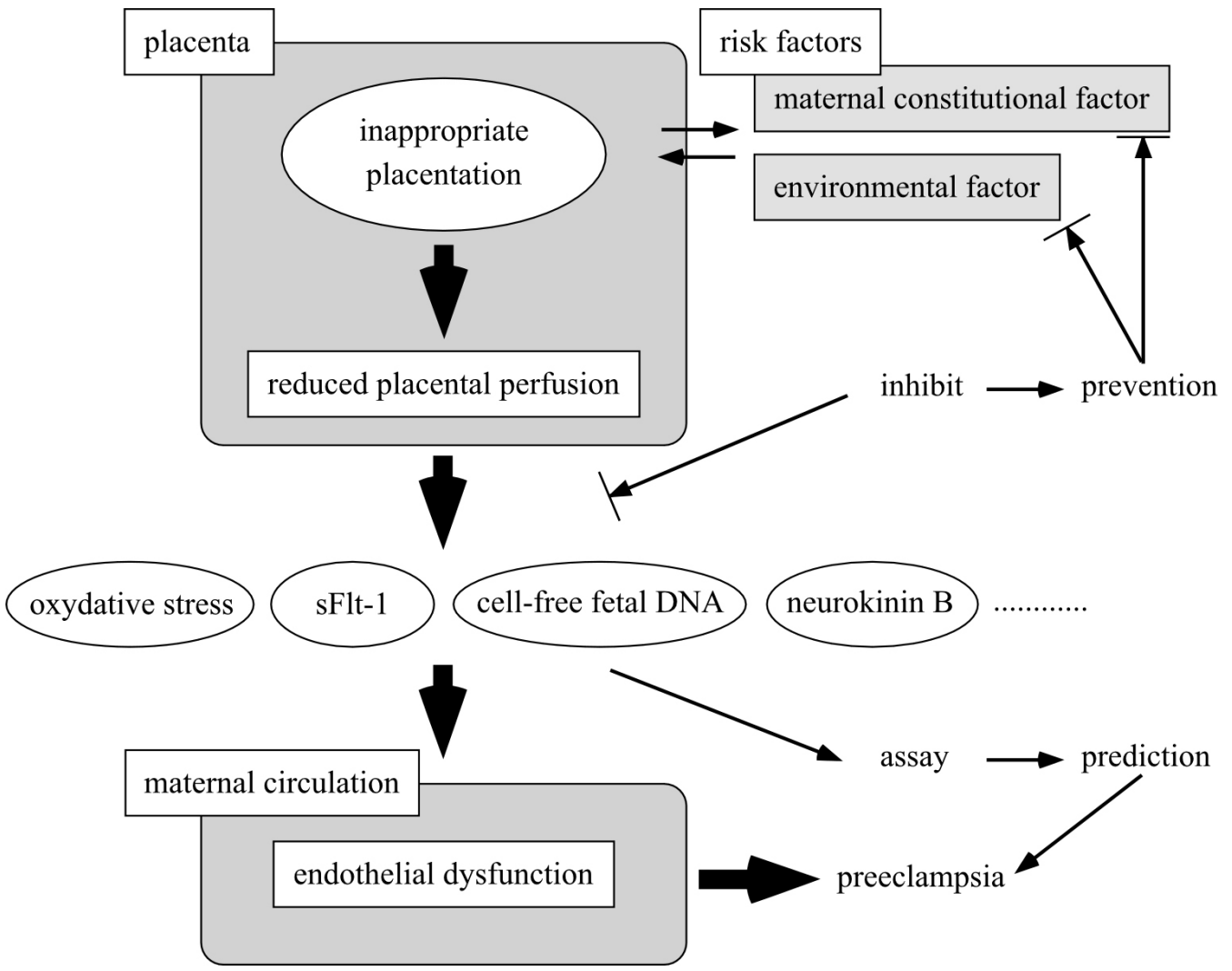

Fig. (1). Reduced placental perfusion is a key of the pathophysiology of preeclampsia. Soluble mediators from preeclamptic placenta lead to maternal systemic vascular endothelial dysfunction. The analysis of soluble mediators could develop the way to predict and prevent preeclampsia.

\section{PERSPECTIVE}

Preeclampsia is a complex disease with multifactoral causes. To date, investigations of its prediction and prevention have not been completely successful. Clinicians do not yet have predictive and preventive standards for preeclampsia. Development of an effective combination of biochemical markers is necessary to identify high-risk women and to take steps to prevent preeclampsia occurrence (Fig. 1). Recently, DNA and RNA [105] in plasma derived from preeclamptic patients has been investigated to predict the occurrence of preeclampsia. Multivariable analysis of a combination of DNA, RNA, and protein in plasma might be needed in order to achieve a reliable method for predicting preeclampsia onset. We hope that recent findings in the field of blood analysis may further our abilities to manage preeclampsia in the future. The prediction and prevention of preeclampsia remains a clinical issue in maternal and fetal health.

\section{REFERENCES}

[1] Sibai BM, Ewell M, Levine RJ, et al. Risk factors associated with preeclampsia in healthy nulliparous women. The calcium for preeclampsia prevention (CPEP) study group. Am J Obstet Gynecol 1997; 177: 1003-10.

[2] Jantasing S, Tanawattanacharoen S. Perinatal outcomes in severe preeclamptic women between 24-33 (+6) weeks' gestation. J Med Assoc Thai 2008; 91: 25-30.

[3] Buchbinder A, Sibai BM, Caritis S, et al. Adverse perinatal outcomes are significantly higher in severe gestational hypertension than in mild preeclampsia. Am J Obstet Gynecol 2002; 186: 66-71.

[4] Farag K, Hassan I, Ledger WL. Prediction of preeclampsia: can it be achieved? Obstet Gynecol Surv 2004; 59: 464-82.
Caritis S, Sibai B, Hauth J, et al. Predictors of pre-eclampsia in women at high risk. National Institute of Child Health and Human Development Network of Maternal-Fetal Medicine Units. Am J Obstet Gynecol 1998; 179: 946-51.

[6] Kaaja R. Predictors and risk factors of pre-eclampsia. Minerv Ginecol 2008; 60: 421-9.

[7] Duckitt K, Harrington D. Risk factors for pre-eclampsia at antenatal booking: systematic review of controlled studies. BMJ 2005; 330: Epub (1-7)

[8] Sutherland A, Cooper DW, Howie PW, Liston WA, MacGillivray I. The indicence of severe pre-eclampsia amongst mothers and mothers-in-law of pre-eclamptics and controls. Br J Obstet Gynaecol 1981; 88: 785-91.

[9] Odegård RA, Vatten LJ, Nilsen ST, Salvesen KA, Austgulen R. Risk factors and clinical manifestations of pre-eclampsia. BJOG 2000; 107: 1410-6.

[10] Bianco AT, Smilen SW, Davis Y, et al. Pregnancy outcome and weight gain recommendations for the morbidly obese woman. $\mathrm{Ob}$ stet Gynecol 1998; 91: 97-102.

[11] Sebire NJ, Jolly M, Harris J, Regan L, Robinson S. Is maternal underweight really a risk factor for adverse pregnancy outcome? A population-based study in London. BJOG 2001; 108: 61-6.

[12] Coonrod DV, Hickok DE, Zhu K, Easterling TR, Daling JR. Risk factors for preeclampsia in twin pregnancies: a population-based cohort study. Obstet Gynecol 1995; 85: 645-50.

[13] Bianco A, Stone J, Lynch L, et al. Pregnancy outcome at age 40 and older. Obstet Gynecol 1996; 87: 917-22.

[14] Garner PR, D'Alton ME, Dudley DK, Huard P, Hardie M. Preeclampsia in diabetic pregnancies. Am J Obstet Gynecol 1990, 163: 505-8.

[15] Mayer DC, Thorp J, Baucom D, Spielman FJ. Hyperthyroidism and seizures during pregnancy. Am J Perinatol 1995; 12: 192-4.

[16] Yasuda M, Takakuwa K, Tokunaga A, Tanaka K. Prospective studies of the association between anticardiolipin antibody and outcome of pregnancy. Obstet Gynecol 1995; 86: 555-9. 
[17] Robertson SA, Bromfield JJ, Tremellen KP. Seminal 'priming' for protection from preeclampsia - a unifying hypothesis. J Reprod Immunol 2003; 59: 253-65.

[18] Mattar R, Amed AM, Lindsey PC, Sass N, Daher S, Preeclampsia and HIV infection. Eur J Obstet Gynecol Reprod Biol 2004; 117 : 240-1.

[19] Nakamura T, Ito M, Kawasaki N. The clinical value of the false positive angiotensin sensitivity test. Clin Exp Hypertens 1984; B3: 178.

[20] Moutquin JM, Rainville C, Giroux L, et al. prospective study of blood pressure in pregnancy: prediction of preeclampsia. Am J Obstet Gynecol 1985; 151: 191-6.

[21] Marya RK, Rathee S, Mittal R. Evaluation of three clinical tests for predicting pregnancy- induced hypertension. Am J Obstet Gynecol 1988; 158: 683-4.

[22] Gant NF, Chand S, Worley RJ, et al. A clinical test useful for predicting the development of acute hypertension in pregnancy. Am J Obstet Gynecol 1974; 120: 1-7.

[23] Kassar NS, Aldridge J, Quirk B. Roll over test. Obstet Gynecol 1980; 55: 411-3.

[24] Tomoda S, Kitanaka T, Ogita S, Hidaka A. Prediction of pregnancy-induced hypertension by isometric exercise. Asia Oceania J Obstet Gynaecol 1994; 20: 249-55.

[25] Nakamura T, Ito M, Matsui K, et al. Significance of angiotensin sensitivity test for prediction of pregnancy-induced hypertension. Obstet Gynecol 1986; 67: 388-94

[26] Conde-Agudelo A, Villar J, Lindheimer M. World Health Organization systematic review of screening tests for preeclampsia. Obstet Gynecol 2004; 104: 1367-91.

[27] Yu CK, Smith GC, Papageorghiou AT, Cacho AM, Nicolaides KH. Fetal Medicine Foundation Second Trimester Screening Group. An integrated model for the prediction of preeclampsia using maternal factors and uterine artery doppler velocimetry in unselected lowrisk women. Am J Obstet Gynecol 2005; 193: 429-36.

[28] Papageorghiou AT, Yu CK, Bindra R, Pandis G, Nicolaides KH; Fetal Medicine Foundation Second Trimester Screening Group. Multicenter screening for pre-eclampsia and fetal growth restriction by transvaginal uterine artery doppler at 23 weeks of gestation. U1trasound Obstet Gynecol 2001; 18: 441-9.

[29] North RA, Ferrier C, Long D, Townend K, Kincaid-Smith P. Uterine artery Doppler flow velocity waveforms in the second trimester for the prediction of preeclampsia and fetal growth retardation. Obstet Gynecol 1994; 83: 378-86.

[30] Brodszki J, Länne T, Laurini R, et al. Vascular mechanical properties and endothelial function in pre-eclampsia with special reference to bilateral uterine artery notch. Acta Obstet Gynecol Scand 2008; 87: 154-62.

[31] Conde-Agudelo A, Villar J, Lindheimer M. World Health Organization systematic review of screening tests for preeclampsia. Obstet Gynecol 2004; 104: 1367-91.

[32] Prefumo F, Fratelli N, Ganapathy R, et al. First trimester uterine artery Doppler in women with previous pre-eclampsia. Acta Obstet Gynecol Scand 2008; 24: 1-5.

[33] Roberts J, Taylor R, Musci T, et al. Preeclampsia. An endothelial cell disorder. Am J Obstet Gynecol 1989; 161: 1200-4.

[34] Wu K. Endothelial prostaglandin and nitric oxide synthesis in atherogenesis and thrombosis. J Formos Med Assoc 1996; 95: 6616.

[35] Sellati T, Burns M, Ficazzola M, Furie M. Borrelia burgdorferi upregulates expression of adhesion molecules on endothelial cells and promotes transendothelial migration of neutrophils in vitro. Infect Immun 1995; 63: 4439-47.

[36] Drexler H, Hornig B. Endothelial dysfunction in human disease. J Mol Cell Cardiol 1999; 31: 51-60.

[37] Murphy JF, O'Riordan J, Newcombe RG, Coles EC, Pearson JF. Relation of haemoglobin levels in first and second trimesters to outcome of pregnancy. Lancet 1986; 1: 992-5.

[38] Aydin S, Benian A, Madazli R, et al. Plasma malondialdehyde, superoxide dismutase, $\mathrm{sE}$-selectin, fibronectin, endothelin-1 and nitric oxide levels in women with preeclampsia. Eur J Obstet Gynecol Reprod Biol 2004; 113: 21-5.

[39] Stubbs TM, Lazarchick J, Horger EO. Plasma fibronectin levels in preeclampsia: a possible biochemical marker for vascular endothelial damage. Am J Obstet Gynecol 1984; 150: 885-7.
[40] Lockwood CJ, Peters JH. Increased plasma levels of ED1+ cellular fibronectin precede the clinical signs of preeclampsia. Am J Obstet Gynecol 1990; 162: 358-62

[41] Emonts P, Seaksan S, Seidel L, et al. Prediction of maternal predisposition to preeclampsia. Hypertens Pregnancy 2008; 27: 23745 .

[42] Chappell LC, Seed PT, Briley A, et al. A longitudinal study of biochemical variables in women at risk of preeclampsia. Am J Obstet Gynecol 2002; 187: 127-36.

[43] Borzychowski AM, Sargent IL, Redman CWG. Inflammation and pre-eclampsia. Semin Fetal Neonatal Med 2006; 11: 309-16.

[44] Vandermeeren M, Janssens S, Borgers M, Geysen J. Dimethylfumarate is an inhibitor of cytokine-induced E-selectin, VCAM-1, and ICAM-1 expression in human endothelial cells. Biochem Biophys Res Comm 1997; 234: 19-23

[45] Raijmakers MTM, Dechend R, Poston L. Oxidative stress and preeclampsia: rationale for antioxidant clinical trials. Hypertension 2004; 44: 374-80.

[46] Matsubara K, Abe E, Ochi H, Kusanagi Y, Ito M. Change of serum concentrations of tumor necrosis factor $\alpha$ and adhesion molecules in normal pregnant women and those with pregnancy-induced hypertension. J Obstet Gynaecol Res 2003; 29: 422-6.

[47] Sahin S, Akoglu T, Direskeneli H, Sen L, Lawrence R. Neutrophil adhesion to endothelial cells and factors affecting adhesion in patients with Behcet's disease. Ann Rheum Dis 1996; 55: 128-33.

[48] Wagener F, Feldman E, Witte T, Abraham N. Heme induces the expression of adhesion molecules ICAM-1, VCAM-1, and E selectin in vascular endothelial cells. PSEBM 1997; 216: 456-63.

[49] Dadak C, Kefalides A, Sinzinger H, Weber G. Reduced umbilical artery prostacyclin formation in complicated pregnancies. Am J Obstet Gynecol 1982; 144: 792-5

[50] Yoshizumi M, Perrella M, Burnett J, Lee M. Tumor necrosis factor downregulates an endothelial nitric oxide synthase mRNA by shortening its half-life. Circ Res 1993; 73: 205-9.

[51] Meekins JW, Pijnenborg R, Hanssens M, van Assche A, McFadyen IR. A study of placental bed spiral arteries and trophoblast invasion in normal and severe pre-eclamptic pregnancies. Br J Obstet Gynaecol 1994; 101: 669-74

[52] Pijnenborg R, Dixon G, Robertson WB, Brosens I. Trophoblastic invasion of human decidua from 8 to 18 weeks of pregnancy. Placenta 1980;1:3-19.

[53] van Wijk IJ, Tjoa ML, ten Tusscher BL, et al. Identification of invasive extravillous trophoblast cells. In: Macek M, Bianchi DW, Cuckle H, Eds: Early Prenatal Diagnosis, Fetal cells and DNA in the Mother: present state and perspectives. The Karolinum Press: Charles University Prague, 2002; 3-22.

[54] Schiessl B, Innes BA, Bulmer JN, et al. Localization of angiogenic growth factors and their receptors in the human placental bed throughout normal human pregnancy. Placenta 2009; 30: 79-87.

[55] Torry DS, Wang HS, Wang TH, Caudle MR, Torry RJ. Preeclampsia is associated with reduced levels of placenta growth factor. Am J Obstet Gynecol 1999; 179: 1539-44.

[56] Tjoa ML, van Vugt JM, Mulders MA, et al. Plasma placenta growth factor levels in midtrimester pregnancies. Obstet Gynecol 2001; 98: 600-7.

[57] Maynard SE, Min JY, Merchan J, et al. Excess placental soluble fms-like tyrosine kinase 1 (sFlt1) may contribute to endothelial dysfunction, hypertension, and proteinuria in preeclampsia. J Clin Invest 2003; 111: 649-58.

[58] Levine RJ, Maynard SE, Qian C, et al. Circulating angiogenic factors and the risk of preeclampsia. N Engl J Med 2004; 350: 67283.

[59] Lo YM. Fetal DNA in maternal plasma. Ann NY Acad Sci 2000; 906: 141-7.

[60] Lun FFM, Chiu RWK, Leung TY, et al. Epigenetic analysis of RASSF1A gene in cell-free DNA in amniotic fluid. Clin Chem 2007; 53: 796-8

[61] Zhong XY, HolzgreveW, Hahn S. Cell-free fetal DNA in the maternal circulation does not stem from the transplacental passage of fetal erythroblasts. Mol Hum Reprod 2002; 8: 864-70.

[62] Redman CW, Sargent IL. Circulating microparticles in normal pregnancy and pre-eclampsia. Placenta 2008; 29 (Suppl A): S73-7.

[63] Reddy A, Zhong XY, Rusterholz C, et al. The effect of labour and placental separation on the shedding of syncytiotrophoblast microparticles, cell-free DNA and mRNA in normal pregnancy and pre-eclampsia. Placenta 2008; 29: 942-9. 
[64] Chiu RW, Chim SS, Wong IH, et al. Hypermethylation of RASSF1A in human and rhesus placentas. Am J Pathol 2007; 170: 941-50.

[65] Tsui DW, Chan KC, Chim SS, et al. Quantitative aberrations of hypermethylated RASSF1A gene sequences in maternal plasma in pre-eclampsia. Prenat Diagn 2007; 27: 1212-8.

[66] Longmore J, Hill RG, Hargreaves RJ. Neurokinin-receptor antagonists: pharmacological tools and therapeutic drugs. Can J Physiol Pharmacol 1997; 75: 612-21.

[67] Moussaoui SM, Le Prado N, Bonici B, et al. Distribution of neurokinin $\mathrm{B}$ in rat spinal cord and peripheral tissues: comparison with neurokinin $\mathrm{A}$ and substance $\mathrm{P}$ and effects of neonatal capsaican treatment. Neuroscience 1992; 48: 969-78.

[68] Sakamoto R, Osada H, Iitsuka Y, et al. Profile of neurokinin B concentrations in maternal and cord blood in normal pregnancy. Clin Endocrinol (Oxf) 2003; 58: 597-600.

[69] Page NM, Woods RJ, Gardiner SM, et al. Excessive placental secretion of neurokinin B during the third trimester causes preeclampsia. Nature 2000; 405: 797-800.

[70] Geissbuehler V, Hillermann R, Czarniecki J, et al. Third trimester plasma neurokinin B levels in women with and without preeclampsia. J Matern Fetal Neonatal Med 2008; 21: 95-100.

[71] Page NM, Dakour J, Morrish DW. Gene regulation of neurokinin B and its receptor NK3 in late pregnancy and pre-eclampsia. Mol Hum Reprod 2006; 12: 427-33.

[72] Bainbridge SA, Roberts JM. Uric acid as a pathogenic factor in preeclampsia. Placenta 2008; 29: S67-72.

[73] Simic MG, Jovanovic SV. Antioxidation mechanisms of uric acid. J Am Chem Soc 1989; 111: 5778-82.

[74] Hink HU, Santanam N, Dikalov S, et al. Peroxidase properties of extracellular superoxide dismutase: role of uric acid in modulating in vivo activity. Arterioscler Thromb Vasc Biol 2002; 22: 1402-8.

[75] Abuja PM. Ascorbate prevents prooxidant effects of urate in oxidation of human low density lipoprotein. FEBS Lett 1999; 446: 3058 .

[76] Johnson RJ, Kang D-H, Feig D, et al. Is there a pathogenetic role for uric acid in hypertension and cardiovascular and renal Disease? Hypertension 2003; 41: 1183-90.

[77] Simic MG, Jovanovic SV. Antioxidation mechanisms of uric acid. J Am Chem Soc 1989; 111: 5778-82.

[78] Maples KR, Mason RP. Free radical metabolite of uric acid. J Biol Chem 1988; 263: 1709-12.

[79] Abuja PM. Ascorbate prevents prooxidant effects of urate in oxidation of human low density lipoprotein. FEBS Lett 1999; 446: 3058 .

[80] Roberts JM, Bodnar LM, Lain KY, et al. Uric acid is as important as proteinuria in identifying fetal risk in women with gestational hypertension. Hypertension 2005; 46: 1263-9.

[81] Tsukimori K, Yoshitomi T, Morokuma S, Fukushima K, Wake N. Serum uric acid levels correlate with plasma hydrogen peroxide and protein carbonyl levels in preeclampsia. Am J Hypertens 2008 [Epub ahead of print].

[82] Hubel CA, Roberts JM, Taylor RN, et al. Lipid peroxidation in pregnancy: new perspectives on preeclampsia. Am J Obstet Gynecol 1989; 161: 1025-34

[83] Redman CWG, Sargent IL. Pre-eclampsia, the placenta and the maternal systemic inflammatory response -a review. Placenta 2003; 24: S21-7.

[84] Raijmakers MT, Peters WH, Steegers EA, Poston L. Amino thiols, detoxification and oxidative stress in pre-eclampsia and other disorders of pregnancy. Curr Pharm Des 2005; 11: 711-34.
[85] Kharb S. Low whole blood glutathione levels in pregnancies complicated by preeclampsia and diabetes. Clin Chim Acta 2000; 294: 179-83.

[86] Mikhail MS, Anyaegbunam A, Garfinkel D, et al. Preeclampsia and antioxidant nutrients: decreased plasma levels of reduced ascorbic acid, alpha-tocopherol, and beta-carotene in women with preeclampsia. Am J Obstet Gynecol 1994; 171: 150-7.

[87] Quinn MJ. Preeclampsia and partial uterine denervation. Med Hypoth 2005; 64: 449-54

[88] Hobson MI, Green CJ, Terenghi G. VEGF enhances intraneural angiogenesis and improves nerve regeneration after axotomy. J Anat 2000; 197: 591-60.

[89] Hofmeyr GJ, Duley L, Atallah A. Dietary calcium supplementation for prevention of pre-eclampsia and related problems: a systematic review and commentary. BJOG 2007; 114: 933-43.

[90] Wallenburg HC, Dekker GA, Makovitz JW, Rotmans P. Low-dose aspirin prevents pregnancy-induced hypertension and preeclampsia in angiotensin-sensitive primigravidae. Lancet 1986; 1 : $1-3$.

[91] Trudinger BJ, Cook CM, Thompson RS, Giles WB, Connelly A. Low-dose aspirin therapy improves fetal weight in umbilical placental insufficiency. Am J Obstet Gynecol 1988; 159: 681-5.

[92] McParland P, Pearce JM, Chamberlain GV. Doppler ultrasound and aspirin in recognition and prevention of pregnancy-induced hypertension. Lancet 1990; 335:1552-5.

[93] Caritis S, Sibai B, Hauth J, et al. Low-dose aspirin to prevent preeclampsia in women at high risk. National Institute of Child Health and Human Development Network of Maternal-Fetal Medicine Units. N Engl J Med 1998; 338: 701-5.

[94] Ito M, Koyama H, Ohshige A, et al. Prevention of preeclampsia with calcium supplementation and vitamin D3 in an antenatal protocol. Int J Gynaecol Obstet 1994; 47: 115-20.

[95] Villar J, Belizan JM, Fischer PJ. Epidemiologic observations on the relationship between calcium intake and eclampsia. Int J Gynaecol Obstet 1983; 21:271-8.

[96] Levine RJ, Hauth JC, Curet LB, et al. Trial of calcium to prevent preeclampsia. N Engl J Med 1997; 337: 69-76.

[97] Dauchet L, Amouyel P, Hercberg S, Dallongeville J. Fruit and vegetable consumption and risk of coronary heart disease: A metaanalysis of cohort studies. J Nutr 2006; 136: 2588-93.

[98] Bodnar LM, Tang G, Ness RB, Harger G, Roberts JM. Periconceptional multivitamin use reduces the risk of preeclampsia. Am J Epidemiol 2006; 164: 470-7.

[99] Carter JP, Furman T, Hutcheson HR. Preeclampsia and reproductive performance in a community of vegans. South Med J 1987; 80 692-7.

[100] Brown DJ, Goodman J. A review of vitamins A, C, and E and their relationship to cardiovascular disease. Clin Excell Nurse Pract 1998; 2: 10-22.

[101] Azzi A, Ricciarelli R, Zingg JM. Non-antioxidant molecular functions of alpha- tocopherol (vitamin E). FEBS Lett 2002; 519: 8-10.

[102] Chappell LC, Seed PT, Briley AL, et al. Effect of antioxidants on the occurrence of pre-eclampsia in women at increased risk: a randomized trial. Lancet 1999; 345: 810-6.

[103] Stanner SA, Hughes J, Kelly CNM, Buttriss J. A review of the epidemiological evidence for the 'antioxidant hypothesis'. Public Health Nutr 2004; 7: 407-22.

[104] Honarbakhsh S, Schachter M. Vitamins and cardiovascular disease. Br J Nutr 2008; 1: 1-19.

[105] Purwosunu Y, Sekizawa A, Okazaki S, et al. Prediction of preeclampsia by analysis of cell-free messenger RNA in maternal plasma. Am J Obstet Gynecol 2009; 200: 386.e1-7. 